\title{
A simple metric of landscape fire exposure
}

\author{
Jennifer L. Beverly (D) - Neal McLoughlin • Elizabeth Chapman
}

Received: 9 March 2020/Accepted: 23 November 2020/Published online: 16 January 2021

(C) The Author(s) 2021

\begin{abstract}
Context Proximity of landcover elements to each other will enable or constrain fire spread. Assessments of potential fire propagation across landscapes typically involve empirical or simulation models that estimate probabilities based on complex interactions among biotic and abiotic controls.

Objectives We developed a metric of landscape fire exposure based solely on a grid cell's proximity to nearby hazardous fuel capable of transmitting fire to its location. To evaluate accuracy of this new metric, we asked: Do burned areas occur preferentially in locations with high exposure?

Methods We mapped exposure to hazardous fuels in Alberta, Canada using a neighbourhood analysis. Correspondence between exposure and 2331 fires that burned 2,606,387 ha following our 2007 assessment was evaluated and exposure changes between 2007 and 2019 were assessed.
\end{abstract}

Supplementary Information The online version contains supplementary material available at https://doi.org/10.1007/ s10980-020-01173-8.

J. L. Beverly ( $ه)$

Department of Renewable Resources, University of

Alberta, Edmonton, AB T6G 2H1, Canada

e-mail: jen.beverly@ualberta.ca

N. McLoughlin · E. Chapman

Forestry Division, Alberta Agriculture and Forestry, 9920 - 108 Street, Edmonton, AB T5K 2M4, Canada
Results In all eleven ecological units analysed, burned area surpluses occurred where exposure was $\geq 60 \%$ and corresponding deficits occurred where exposure was $<40 \%$. In seven ecological units, the majority of burned areas had pre-fire exposure $\geq 80 \%$. Between 2007 and 2019, land area with exposure $\geq 80 \%$ increased by almost a third.

Conclusions Exposure to hazardous fuels is easily quantified with a single thematic layer and aligns well with subsequent fires in Boreal, Foothills and Rocky Mountain natural regions. The resulting fire exposure metric is a numeric rating of the potential for fire transmission to a location given surrounding fuel composition and configuration, irrespective of weather or other fire controls. Exposure can be compared across geographic regions and time periods; and used in conjunction with other metrics of fire controls to inform the study of landscape fire.

Keywords Landscape modeling - Complexity · Fire growth - Wildfire risk assessment - Burn probability · Simulation · Forest fire management

\section{Introduction}

In fire-prone ecosystems, the pattern of different vegetation types, stand-ages, burned areas, and nonfuel creates landscape heterogeneity that modulates 
fire behaviour (Turner and Romme 1994; Peterson 2002; McKenzie et al. 2011). Spatial arrangement of vegetation and other cover types are considered bottom-up (endogenous) controls on fire propagation that interact with top-down (exogenous) controls such as long-term climatic patterns and weather conditions (Simard 1991; Falk et al. 2007; McKenzie et al. 2011; Newman et al. 2019). The study of how neighbouring landscape elements interact with each other and with overlying ecological processes is a central concern in landscape ecology that has motivated development of quantitative landscape metrics for describing the physical expression of pattern-process dynamics (White 1987; Turner 1989; Pickett and Cadenasso 1995; Walz 2011; Gustafson 2019). Measures of landscape contagion and resistance are used to quantify the structural characteristics of landscapes that either facilitate or constrain the movement of an agent or process (Newman et al. 2019). In the case of habitat fragmentation and the movement of organisms, metrics of contagion can be used to measure the configuration and aggregation of landscape elements based on cell-adjacencies calculated from a single thematic layer of cover types (e.g., O'Neill et al. 1988; Turner 1989; Li and Reynolds 1993; McGarigal and Marks 1995; Riitters et al. 1996). Landscape analysis of potential wildfire movement is complicated by interacting biotic and abiotic controls on fire processes that have spawned complex empirical and simulation modelling frameworks.

Historical fire edges have been used to study the influence of fire environment variables and anthropogenic factors on landscape fire resistance with binary predictive statistical models (e.g., Narayanaraj and Wimberly 2011; Holsinger et al. 2016; Macauley 2020) and machine learning methods (e.g., O'Connor et al. 2017; Rodrigues et al. 2020). Unfortunately, resulting predictive models do not provide a standardized and generalizable characterization of landscape fire that can be applied across large areas, due to spatial and temporal non-stationarity in the underlying statistical relationships and historical data that is often incomplete, inconsistent or unreliable over broad areas. Simulation models offer an alternative framework for exploring the potential for fire movement across landscapes using a variety of approaches reviewed by Perry (1998) and Papadopoulos and Pavlidou (2011).
Widely used fire growth models like FARSITE (Finney 2004) and Prometheus (Tymstra et al. 2010) simulate the deterministic movement of an individual fire using fire environment inputs that describe fuel, weather and topographic conditions. These models of discrete fire events are extended to landscape assessments with Monte Carlo simulations such as FSim (Finney et al. 2011) and Burn-P3 (Parisien et al. 2005) that model the spread of multiple fires from stochastic ignitions and weather in large numbers of repeated iterations to calculate the probability of a grid-cell burning. Simulated burn probability maps have been used to explore the influence of landscape configuration and fuel discontinuities on fire spread across natural landscapes (e.g., Beverly et al. 2009; Ager et al. 2012; Stockdale et al. 2019) as well as theoretical landscapes generated with varying configurations (e.g., Finney 2007; Parisien et al. 2010). Despite their popularity, simulated burn probability maps have exhibited poor alignment with subsequent observed wildfires and may not be informative in regions characterized by infrequent fire and low probabilities of burning (Beverly and McLoughlin 2019). Alternate simulation frameworks exist for modelling the movement of fire across raster landscapes (e.g., Finney 2002, 2006; Gray and Dickson 2015; Conver et al. 2018); however, all models that simulate fire spread must account for highly stochastic abiotic controls on fire, such as ignition locations and weather, which introduce numerous data requirements, computational complexities, and accumulated uncertainty.

Rapid expansion of landscape fire simulation modelling in the 1990s coincided with a broader trend towards increasingly complex and data-intensive approaches for representing multifaceted ecological processes in landscape models (Larsen et al. 2016; Getz et al. 2018). Perera et al. (2015) note the lack of consensus among ecologists about the desirability of simple, parsimonious models versus complex simulations of disturbance processes. The question of appropriate model complexity has been largely ignored by wildland fire modelers, despite it being a topic of high importance in other ecological disciplines (e.g., Murray 2007; Collie et al. 2016; Larsen et al. 2016; Getz et al. 2018; Baartman et al. 2020). A modeler seeking basic explanation is advised to retain only essential, first-order processes (Murray 2003, 2007). According to Gustafson (2013), modelers should "simulate processes at the most fundamental 
level that is reasonable, while avoiding the temptation to add unnecessary detail just because it is feasible."

Simple relative ratings of fuel moisture and potential fire behaviour (i.e., Van Wagner 1987) based solely on weather measurements irrespective of fuel conditions have long been used to characterize ecological fire processes (e.g., Flannigan and Harrington 1988; Flannigan et al. 2005) and for supporting fire management decisions (Cunningham and Martell 1973; Martell et al. 1987; Wotton and Martell 2005). Comparable fuel-based metrics formulated irrespective of weather have yet to be fully explored, possibly due to the widespread availability and appeal of sophisticated fire growth and simulation modelling frameworks. In this study, we sought to develop a simple landscape metric of fire based solely on stable physical fuel properties decoupled from highly dynamic abiotic controls on fire propagation, notably ignition patterns and weather, which fluctuate over divergent temporal horizons (e.g., minutes, hours and days).

Wildfire propagation will depend in part on the position of flammable landscape elements in relation to each other. Fires spread in a contagious endothermic-exothermic chain reaction that only persists if heat from burning vegetation is successfully transferred over a distance to preheat and ignite adjacent or nearby fuels (Rothermel 1972; Van Wagner 1983; van Wagtendonk 2006). The transmission of fire from one location to another occurs over relatively localized distances associated with wildfire heat transfer mechanisms that include direct contact with flames, radiant heat, and embers (Countryman 1977; Sullivan 2017). In northern forest ecosystems, embers transported by a convective column can transmit fire to locations several kilometres away (MNP 2017); however, empirical observations (e.g., Page et al. 2019) and theoretical models (e.g. Albini 1979) suggest fire transmission from embers occurs predominantly within $500 \mathrm{~m}$, except under the most extreme conditions. Following this simple reasoning, Beverly et al. (2010) used ember distance ranges and the concept of exposure to assess potential wildfire movement into the built-environment based solely on the proximity of a location to nearby hazardous fuels.

Exposure is defined as the extent to which a value, resource, asset or geographic area may be subject to or come into contact with a potential source of harm (ISO 2009; Thompson et al. 2016). A potential source of harm may relate to the process itself (i.e., an actively burning wildfire is the hazard) or the preconditions necessary for that process to occur, in which fuels are the hazardous condition that can result in a wildfire (Hardy 2005). Exposure assessments typically characterize the juxtaposition of values, such as built structures, with geographic locations where burning is possible (e.g., Beverly et al. 2010) or probable (e.g., Haas et al. 2013; Whitman et al. 2013); however, the concept is equally relevant to the transmission of fire from hazardous fuel to nearby flammable vegetation.

Exposure is not an event whose probability of occurrence can be estimated, but rather it is a physical quantity whose value at any point in time and space can be measured. We adapted the exposure method developed by Beverly et al. (2010) to map exposure to hazardous fuels in Alberta, Canada using a neighbourhood analysis. Exposure was estimated for a landscape grid at the cell level by the proportion of neighbourhood cells that contain hazardous fuel types. The resulting exposure metric describes the extent to which land cover type in the vicinity of a location will either contribute to or resist fire transmission to that location. The approach explicitly accounts for the contagious nature of combustion without the need for time- and data-intensive simulations of fire growth. To evaluate model performance, we assessed correspondence between exposure mapped for the 2007 assessment year and subsequent observed burned areas and compared results among eleven ecological units within the study area. We hypothesized that most burned areas would occur in locations with exposure $\geq 60 \%$, and that fire deficits would prevail in locations with exposure $<40 \%$. To test the robustness of the approach, we estimated five alternative formulations of the exposure metric in which we varied the size of the focal fuel neighbourhood and introduced weighting schemes to represent within-neighbourhood differences in fuel configuration, fuel load, and potential fire behaviour. Implications of our results for landscape fire ecology, fire management and future research are discussed. 


\section{Methods}

Study area

Exposure to hazardous fuels was assessed for the entire Forest Protection Area (FPA) of the province of Alberta; an area spanning approximately 39 million hectares. Eleven ecological units within the study area were defined by Natural Region and Natural Subregion boundaries (Natural Regions Committee 2006) (Fig. 1). The Rocky Mountain Region was analysed as a single unit, owing to the limited spatial extent of observed burned areas in that region. All other ecological units consisted of interlocking Natural Subregions. The Peace-Athabasca Delta subregion was omitted from analysis due to its small size and lack of observed burned areas. Fire regime characteristics by ecological unit are summarized in Online Appendix A. Descriptions of climate, vegetation, topography, geology, soils and hydrology within each ecological unit are detailed in the reference report Natural Regions and Subregions of Alberta (Natural Regions Committee 2006).
Data

Thematic land cover maps in a raster format with a $100 \mathrm{~m} \times 100 \mathrm{~m}$ resolution were obtained for the years 2007, 2016 and 2019 from the Alberta Wildfire Management Branch. Non-fuel cover-types included water and barren ground; areas disturbed by wildfires or harvesting that are subject to reclassification with time since disturbance; and anthropogenic features such as roads. Flammable cover types were classified according to the standard fuel types used in Canadian fire behavior models (i.e., Forestry Canada Fire Danger Group 1992). Cover type was derived from agency-defined rules applied to three main sources: the Alberta Vegetation Inventory (AVI), 69-72\% of the study area; Alberta Ground Cover Classification (AGCC), 18-21\%; and disturbance inventories compiled by the provincial government, $8-11 \%$. A small portion (i.e., 2\%) of the 2007 fuel map was informed by two photo-based forest inventories from the mid1980s and early 1990s.

AVI is updated every 10-15 years and specifies hydrography, vegetation cover types and stand
Fig. 1 Location of the study area and ecological units within the Forest Protection Area (FPA) of the province of Alberta, Canada

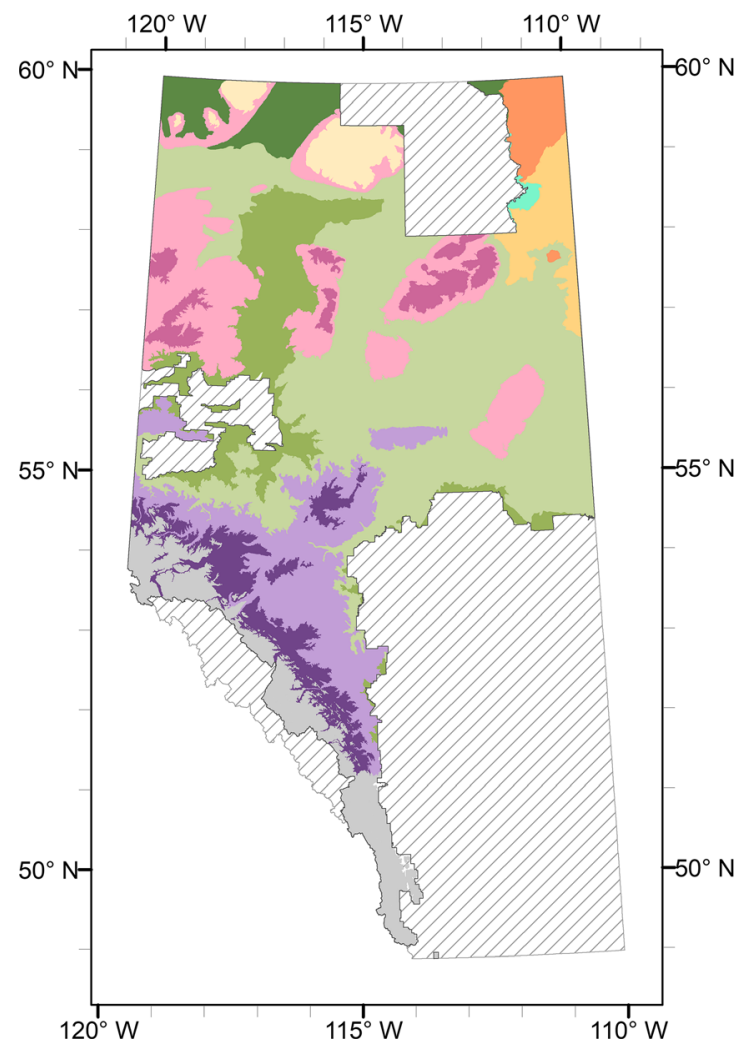

Ecological units

BSA - Boreal Subarctic

AP - Athabasca Plain

KU - Kazan Upland

UF - Upper Foothills

LF - Lower Foothills

UBH - Upper Boreal Highlands

LBH - Lower Boreal Highlands

NM - Northern Mixedwood

DM - Dry Mixedwood

CM - Central Mixedwood

RM - Rocky Mountain

PA - Peace-Athabasca Delta

Outside the Forest

Protection Area (FPA) 
structure attributes from interpreted aerial photographs (Resource Information Management Branch 2005 ) with a minimum polygon size of 2.0 ha, considered valid for use at a scale of 1:20,000. AGCC is derived from Landsat TM5 and TM7 satellite imagery that was last updated in 2000. Land cover is assigned to one of 99 classes describing anthropomorphic features, vegetated uplands, wetlands, water, and barren land at a $30 \mathrm{~m} \times 30 \mathrm{~m}$ resolution considered useful at a 1:50,000 scale (Sánchez-Azofeifa et al. 2004). Disturbance inventories are updated annually and consist of polygon boundaries associated with wildfires, forest harvesting, and land clearing. Recently harvested cut blocks are generally interpreted from aerial photographs to a minimum polygon size of 0.5 ha and a $5 \mathrm{~m}$ level of precision (Resource Information Management Branch 2005). Wildfire polygons are mapped with a variety of methods including ground and airborne Global Positioning Systems (GPS), infrared scanning, digitized aerial photographs, satellite imagery classification, and hand-sketched boundaries. Wildfire polygons for the period 2007-2019 include fires that burned $<1.0$ ha.

Metric estimation

We classified all conifer and mixedwood fuel types as hazardous fuels capable of transmitting fire within a $500 \mathrm{~m}$ distance range. Grid cells that contained these hazardous fuels were assigned a value of " 1 " and all other cells were deemed a non-hazard denoted by " 0 ". For exposure assessments in Boreal and Foothills Natural Regions of Alberta, Beverly et al. (2010) defined three exposure distance ranges $(0-30 \mathrm{~m}$, 0-100 m, and 100-500 m) to represent the spatial extent of different ignition mechanisms (i.e., radiant heat and the transport of short- and longer-range embers). We estimated exposure for a single, $500 \mathrm{~m}$ distance range compatible with our 1 ha resolution land cover raster.

Exposure to hazardous fuels was calculated for each cell in the landscape raster using the focal statistic tool of the ArcGIS Spatial Analyst toolset. We used a circular neighbourhood with a 5-cell $(500 \mathrm{~m})$ radius to sum the binary hazardous fuel grid across 80 cells that surrounded each assessment cell, excluding the assessment cell. Exposure was calculated as the focal statistic sum as a percentage of the maximum possible sum (i.e., of 80 ). By default, the modelling process generates exposure values for all cells in the land cover raster, including non-fuel cells such as rock, water and recently burned lands that are incapable of sustaining combustion, which were therefore discarded prior to further analysis. Exposure values within $500 \mathrm{~m}$ of the study area boundary were also discarded to remove edge-effects.

We estimated exposure to hazardous fuels for three time periods using land cover thematic layers representative of conditions during the 2007, 2016 and 2019 fire seasons. To validate our metric, all available fire polygons between 2007 and 2019 were compiled from the previously described provincial fire disturbance inventory. A total of 2331 fire perimeters encompassing 2,606,387 ha of observed burned areas were used to assess performance of the 2007 pre-fire exposure map. We expected distributions of exposure values in observed burned areas to be skewed towards the highend of the range of values. Model accuracy was assessed based on an expectation that the majority of observed burned areas would have pre-fire exposure $\geq 60 \%$.

To assess the metric's discrimination ability, we used Chi squared tests to detect significant differences between the proportion of observed burned areas with exposure $\geq 80 \%$ and $\geq 60 \%$ compared with the corresponding proportion across the study area as a whole (i.e., the null model). Distributions of exposure values in burned and unburned areas were compared with a Wilcoxon rank sum test. Due to the presence of spatial autocorrelation in the data, we used a random sample of exposure values consisting of a 0.005 portion of the area under assessment to test for significant differences.

Following Beverly et al. (2010), we assumed that all hazardous fuel cells contribute equally to exposure, irrespective of differences in fuel type or configuration within the circular fuel neighbourhood. To account for the possible effect of reduced ember transmission with increasing distance from burning vegetation, we generated a distance-weighted exposure metric with a negative exponential decay function (Eq. 1):

$y=15.197 e^{-0.01 x}$

where $y$ is the weight given to a grid cell that contains a hazardous fuel, $x$ is the distance $(\mathrm{m})$ of the hazardous fuel cell from the grid cell under assessment, 15.197 is the value at distance 0 (i.e., the intercept), and the 
decay rate, $\lambda=0.01$, is the inverse of the average distance between two cells in the grid (i.e., the raster resolution, $100 \mathrm{~m}$ ). In the distance-weighted formulation of the exposure metric, the negative exponential spatial weight matrix was applied to the binary hazardous fuel grid prior to calculating the focal neighbourhood sum for each grid cell. The maximum possible sum of the weighted fuel neighbourhood was equivalent to that of the unweighted formulation (i.e., 80).

To account for possible effects of fuel type and fuel load on the transmission of fire from one cell to another, we estimated exposure weighted by variations in fuel attributes relevant to fire behaviour: crown fuel load $(\mathrm{kg}$ $\mathrm{m}^{-2}$ ), head fire intensity $\left(\mathrm{kW} \mathrm{m}^{-1}\right)$, and rate of spread $\left(\mathrm{m} \mathrm{min}{ }^{-1}\right)$. Fuel attributes by fuel type and associated weights applied to the binary hazardous fuel layer are shown in Table 1. Crown fuel load is the standard load assigned to each fuel type in the Canadian Forest Fire Behaviour Prediction (FBP) System (Forestry Canada Fire Danger Group 1992). Head fire intensity and rate of spread by fuel type were calculated using FBP System equations and fire weather inputs representing 95th percentile conditions, which were derived from a database of almost 20,000 fires in Alberta between 2006 and 2018. In a final variant of the standard exposure metric, we used a $1000 \mathrm{~m}$ circular neighbourhood to test our assumption that fire transmission from one location to another was effectively represented by a $500 \mathrm{~m}$ circular neighbourhood.

Large fires $>1000$ ha were responsible for $97 \%$ of observed burned areas in our study area, which is consistent with dominant Canadian fire regimes where infrequent, high intensity crown fires are typical (Stocks et al. 2002). To assess the sensitivity of the exposure metric to fire size, we compared distributions of exposure values in observed burned areas produced by fires in three different size classes: $\leq 100$ ha, 100.1-1000 ha and $>1000$ ha. We also investigated changes in exposure between 2007 and 2019 and estimated exposure for the 2016 assessment year in the vicinity of the community of Fort McMurray, which was heavily impacted by the Horse River Fire later that same year. To illustrate the unique landscape qualities expressed by the exposure metric, pre-fire exposure for Fort McMurray was then compared with simulated burn probabilities generated with the Burn-P3 model for the same year and location in a prior study (i.e., Beverly and McLoughlin 2019).

\section{Results}

Comparisons of exposure values in burned areas with those across the study area as a whole (i.e., the null model) indicated good discriminatory ability with the

Table 1 Fuel attributes and associated weights by fuel type used to calculate three variants of the exposure metric

\begin{tabular}{|c|c|c|c|c|c|c|}
\hline \multirow[t]{2}{*}{ Hazardous fuel type $^{a}$} & \multirow{2}{*}{$\begin{array}{l}\text { Crown fuel } \\
\text { load }(\mathrm{CFL})^{\mathrm{a}} \\
\left(\mathrm{kg} \mathrm{m}^{-2}\right)\end{array}$} & \multirow{2}{*}{$\begin{array}{l}\text { Head fire intensity } \\
(\mathrm{HFI})^{\mathrm{a}, \mathrm{b}}\left(\mathrm{kW} \mathrm{m}^{-1}\right)\end{array}$} & \multirow{2}{*}{$\begin{array}{l}\text { Rate of spread } \\
(\mathrm{ROS})^{\mathrm{a}, \mathrm{b}} \\
\left(\mathrm{m} \mathrm{min}{ }^{-1}\right)\end{array}$} & \multicolumn{3}{|c|}{ Weight } \\
\hline & & & & CFL & HFI & ROS \\
\hline C-1 Spruce-lichen woodland & 0.75 & 6569 & 10.4 & 0.75 & 0.40 & 0.60 \\
\hline C-2 Boreal spruce & 0.80 & 29,159 & 23.9 & 0.80 & 1.60 & 1.40 \\
\hline C-3 Mature Jack or lodgepole pine & 1.15 & 15,418 & 13.3 & 1.15 & 0.80 & 0.80 \\
\hline C-4 Immature Jack or lodgepole pine & 1.20 & 29,382 & 24.1 & 1.20 & 1.60 & 1.40 \\
\hline C-6 Conifer plantation & 1.80 & 35,053 & 27.6 & 1.80 & 1.90 & 1.60 \\
\hline C-7 Ponderosa pine-Douglas fir & 0.50 & 5489 & 5.9 & 0.50 & 0.03 & 0.30 \\
\hline M-2 Boreal Mixedwood-Green & 0.80 & 9828 & 12.6 & 0.80 & 0.50 & 0.70 \\
\hline Average & 1.00 & 18,700 & 17.0 & 1.00 & 1.00 & 1.00 \\
\hline
\end{tabular}

In each variant, the value assigned to a hazardous fuel cell is weighted according to relative differences in either: crown fuel load (CFL), head fire intensity (HFI) or rate of spread (ROS). HFI and ROS represent 95th percentile fire weather conditions

${ }^{a}$ Fuel types and fire behavior equations from the Canadian Forest Fire Behaviour Prediction (FBP) System (Forestry Canada Fire Danger Group 1992)

${ }^{\mathrm{b}}$ Predicted head fire intensity (HFI) and rate of spread (ROS) represent 95th percentile fire weather associated with reported fires between 2006 and 2018. Fire Weather Index System (Van Wagner 1987) inputs were: Fine Fuel Moisture Code, 92.5; Build-up Index, 92.7; and Initial Spread Index, 14.7 
standard formulation of the metric (Table 2). Burned area surpluses in the study area were associated with exposure $\geq 60 \%$ and burned area deficits with exposure $<40 \%$. None of the five alternative formulations of the exposure metric increased the magnitude of burned area surpluses $(0.20)$ in high exposure areas and burned area deficits $(-0.18)$ in low exposure areas. All further analysis was therefore conducted with the standard formulation of the exposure metric with a $500 \mathrm{~m}$ fuel neighbourhood and an assumption that hazard fuels contribute equally to exposure, irrespective of their distance, fuel load or potential fire behaviour.

Exposure maps for the study area as a whole (Fig. 2) indicate the pattern of landscape fire exposure varies spatially across Alberta and revealed a marked escalation in landscape fire exposure between 2007 and 2019. In ten of eleven ecological units, the majority of observed burned areas had pre-fire exposure $\geq 60 \%$ and in seven of these units, the majority of burned areas had pre-fire exposure $\geq 80 \%$. Between 2007 and 2019, land area with exposure $\geq 80 \%$ increased by almost a third. In all eleven ecological units analysed, burned area surpluses occurred where exposure was $\geq 60 \%$ and corresponding deficits occurred where exposure was $<40 \%$ (Fig. 3). Differences between observed and expected proportions of burned area with exposure $\geq 60 \%$ and $\geq 80 \%$ were significant in all ecological units (Table 3); however, the magnitude of these differences varied. Corresponding burned area deficits were consistently observed in locations where exposure was $<40 \%$. In the Dry Mixedwood ecological unit, the burned area deficit was limited to locations with exposure $<20 \%$.

The strength of evidence provided by distributions of exposure values in burned areas depends on the extent to which low exposure values are represented in the remainder of the area. For example, over $90 \%$ of the Athabasca Plain ecological unit had exposure $\geq 60 \%$, such that a fire positioned randomly within its boundaries would align with high exposure values by default. In most other ecological units, a range of exposure values were represented and observed fires clearly selected for locations with exposure $\geq 60 \%$. The lone exception was the Dry Mixedwood ecological unit, where most land area, as well as burned area, had exposure $<40 \%$, suggesting that fire environment and fire regime attributes or possibly fuel data limitations in that ecological unit confounded results.

Mean exposure to hazardous fuels was significantly lower in unburned areas compared with burned areas (Online Appendix B). Average exposure across the study area as whole was $66.2 \%$ in burned areas and $49.7 \%$ in unburned areas. Within individual ecological units, excepting the Dry Mixedwood, average exposure to hazardous fuels within burned areas was 58-88\% and median exposure was 61-95\%. Average and median exposure to hazardous fuels in unburned areas were significantly lower, but varied substantially among ecological units and on their own offer little insight into metric performance. Exposure to hazardous fuels is not a probabilistic estimate. If exposure values are high in unburned areas, the metric is simply telling us that landscape configuration and composition is conducive to fire spread, should the opportunity for burning arise. In contrast, when large areas assessed as having predominantly high fire resistance (i.e., low exposure) are subsequently observed to burn, it suggests the exposure metric has not effectively characterised aspects of landscape configuration and composition relevant to fire propagation in that ecosystem.

Across the study area, excluding the Dry Mixedwood unit, only $6.5 \%$ of observed burned areas occurred in locations with exposure $<20 \%$. In all ecological units, some low exposure locations subsequently burned, but this was generally limited to a small proportion of the total observed burned area. Three exceptions were the Dry Mixedwood, Central Mixedwood and Lower Foothills ecological units where $73 \%, 28 \%$ and $20 \%$ of burned areas respectively had ignition exposure $<40 \%$. One third of these low-exposure burned areas were associated with a single large fire, the 2019 Chuckegg Creek Fire. This fire was also solely responsible for $92 \%$ of the low exposure areas that burned in the Dry Mixedwood ecological unit, where the metric performed poorly. Burned areas in locations assessed as having low exposure may be attributed to misclassification of land cover due to outdated inventory data or fuel conditions that do not conform well to the standard fuel types used to classify hazardous fuels. Observed burned areas in our eleven ecological units that were associated with ignition exposure $<40 \%$ occurred predominantly in deciduous and grass fuels. 


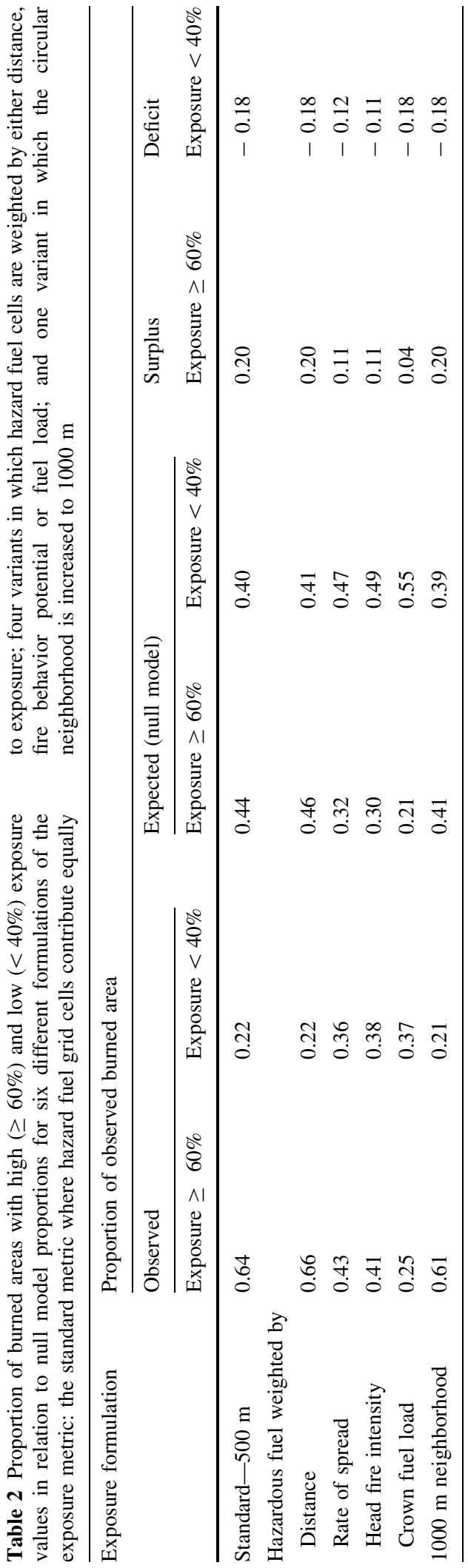

Excluding the Dry Mixedwood ecological unit where the exposure metric performed poorly, $70 \%$ of burned areas occurred in locations with exposure $\geq 60 \%$. Exposure values exhibited some sensitivity to fire size class (Fig. 4). The proportion of burned areas associated with exposure $<20 \%$ increased threefold from 0.06 to 0.18 as fire size-class was reduced from largest ( $>1000$ ha) to smallest ( $\leq 100$ ha). Overall, fire size had a negligible impact on our results due to the extremely small proportion of burned areas $(<3 \%)$ associated with fires $\leq 100$ ha.

Exposure to hazardous fuels in the Fort McMurray area at the start of the 2016 fire season (Fig. 5) indicated the area was highly conducive to fire spread prior to the Horse River fire that destroyed over 3000 structures in the community later that same year. In contrast, burn probabilities simulated for the same location and year in a prior study (i.e., Beverly and McLoughlin 2019) indicated large continuous areas of low to moderate fire likelihood surrounded the entire community of Fort McMurray prior to the fire. Overall, our simple, univariate metric of exposure to hazardous fuels exhibited better alignment with subsequent real-world fires than burn probabilities generated with a complex landscape simulation model (Burn-P3) evaluated in a prior study (Beverly and McLoughlin 2019).

\section{Discussion}

Metric performance

Observed burned areas between 2007 and 2019 in ten of eleven ecological units within our study area occurred predominantly in locations with $\geq 60 \%$ exposure to hazardous fuels. Burned area surpluses were consistently observed in these locations and corresponding deficits were consistently observed in locations with exposure $<40 \%$. The sole exception was the Dry Mixedwood ecological unit, where our metric performed poorly; however, $92 \%$ of the burned area in low exposure areas in that unit were attributed to a single fire, which suggests possible anomalous conditions.

Comparisons of exposure estimated for 2007 and 2019 assessment years revealed a rapid escalation in landscape fire exposure. Over a relatively short 13 -year time period, land area with exposure $\geq 80 \%$ 


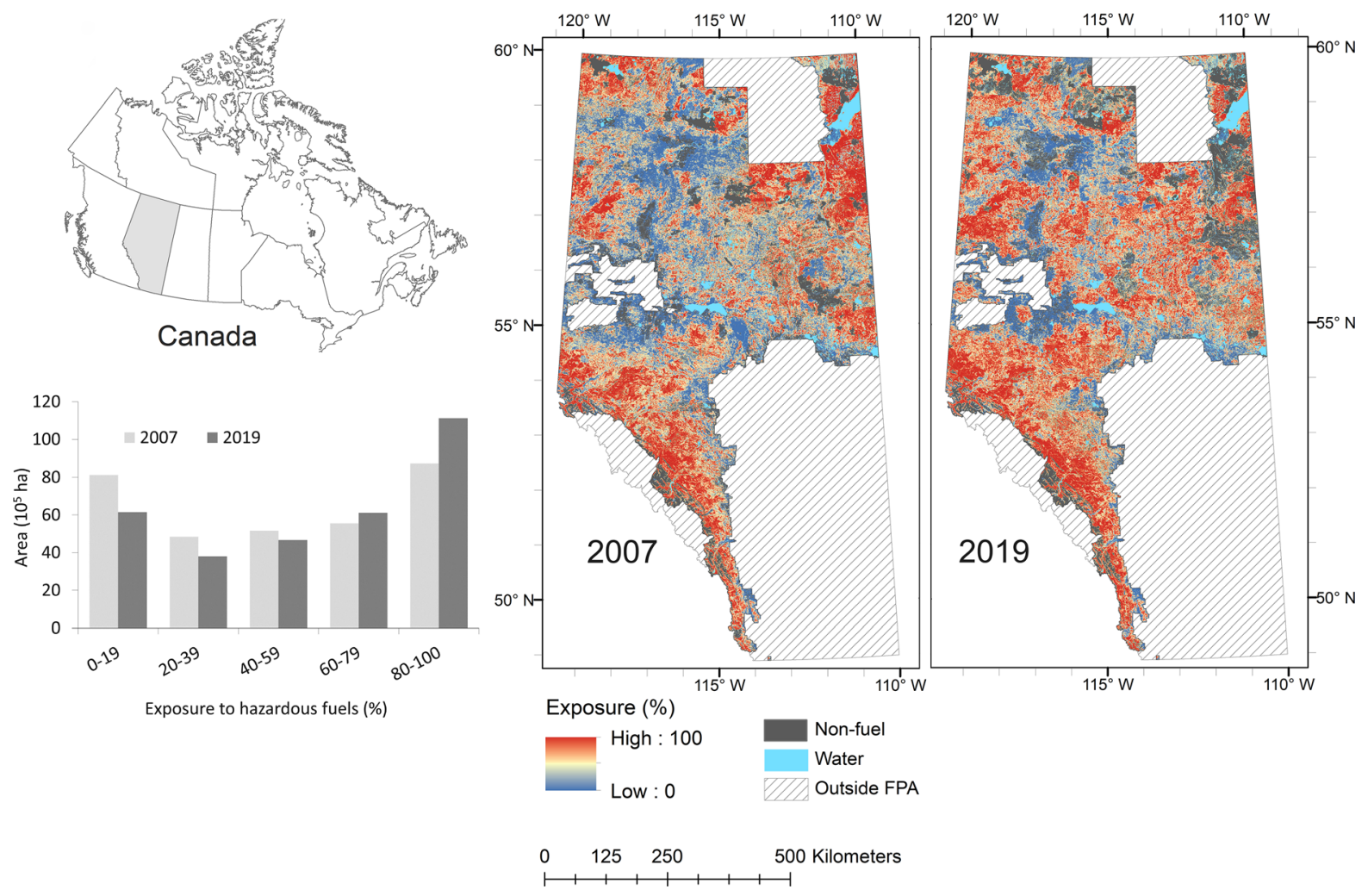

Fig. 2 Exposure to hazardous fuels within the Forest Protection Area of the province of Alberta, Canada, for 2 years: 2007 and 2019

increased by $30 \%$. Some of this change may be an artefact of administrative updates to the fuel grid due to newly available data or changes in subjective decision rules used to classify existing data. Change in the fuel grid is expected to result from state transitions where recently disturbed areas assessed as non-fuel or non-hazardous fuel types transition to a hazardous fuel classification with the passage of time. Irrespective of the underlying source of change, additions of hazardous fuel to the land cover grid between 2007 and 2019 outpaced offsetting deletions that result primarily from new fire and harvest disturbances.

\section{Robustness of the approach}

To test the robustness of our fuel exposure metric, we estimated five alternative formulations in which we varied the size of the focal fuel neighbourhood and introduced weighting schemes to represent withinneighbourhood differences in fuel configuration, fuel load, and potential fire behaviour. None of these variants improved performance of our standard formulation in which a $500 \mathrm{~m}$ fire transmission neighbourhood is used and hazardous fuels within the neighbourhood are assumed to contribute equally to exposure irrespective of their configuration. This result is not surprising. Most of the area burned in Canada is caused by large fires $\geq 200$ ha (Stocks et al. 2002) that burn under relatively uniform and generally very high to extreme fire weather conditions (Amiro et al. 2004). Large fires achieve most of their growth during a relatively small number of "spread event days" (Podur and Wotton 2011) when conditions are typically hot, dry and windy (e.g., Srock et al. 2018) and fuel moisture is uniformly low across large areas. Under these elevated fire weather conditions, we expect the minimum requirements for fire transmission within the $500 \mathrm{~m}$ distance range are being met in hazardous fuel types, regardless of the specific type of hazardous fuels present and regardless of the fuel load, fire intensity, rate of spread, or location of the hazardous fuel cell within the focal neighbourhood.

Fire size had an influence on model performance. When small fire polygons are used to extract exposure 


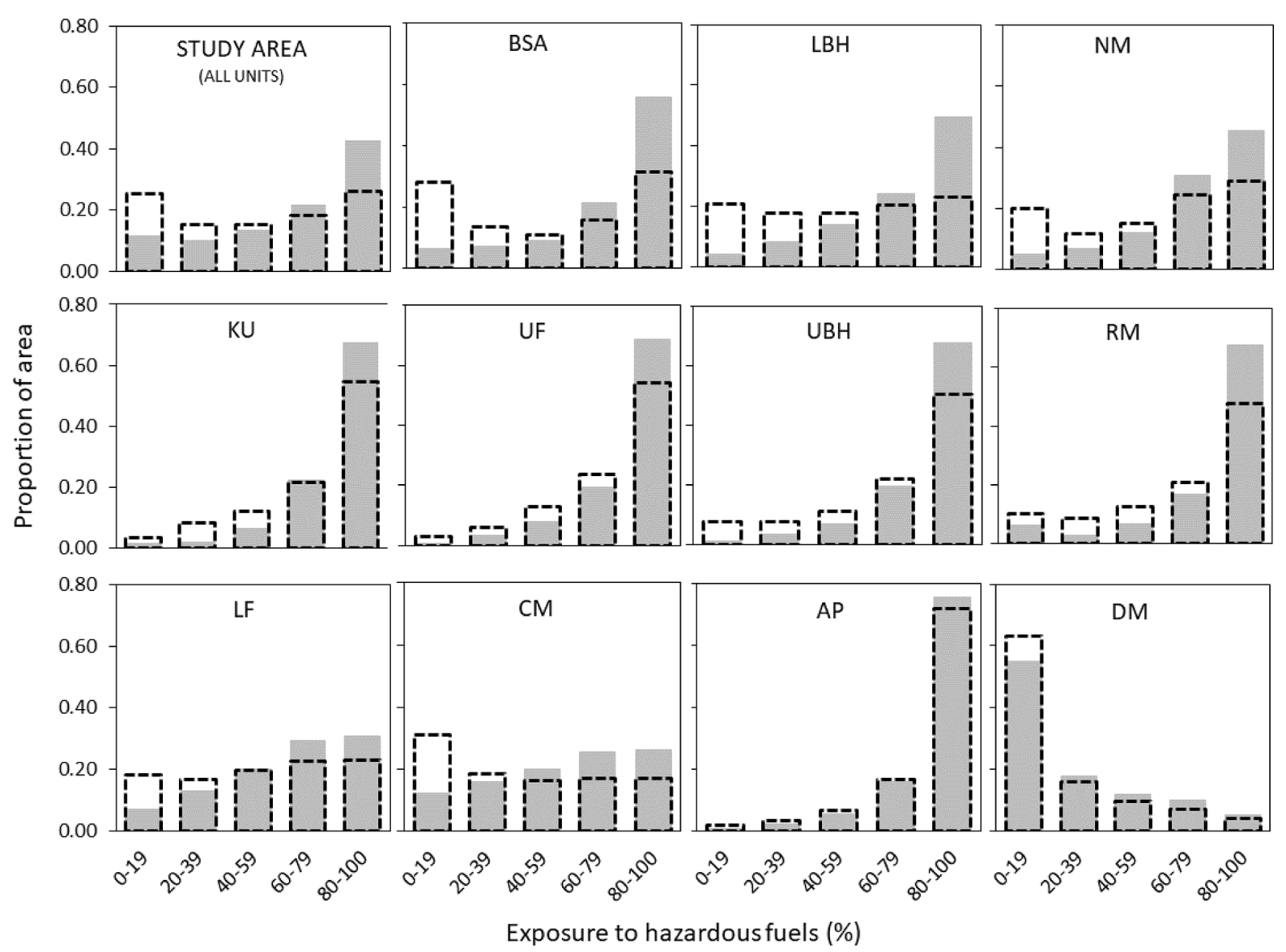

Fig. 3 Proportion of burned area (solid shaded bars) in each exposure class, by study area and ecological unit, versus proportions across the area as a whole (hollow dashed bars). BSA Boreal Subarctic, LBH Lower Boreal Highlands, NM Northern

grid cells with a 1 ha resolution, a high proportion of error-prone edge pixels will result, which could explain declining metric performance with decreasing fire size-class. Declining performance for smaller fires could also be due to these fires burning under comparatively less-extreme conditions, such that shorter-range fire ignition processes become more influential. Fire size had a negligible impact on our results due to the extremely small burned area associated with small fires in our study area. Estimation of the exposure metric in ecosystems characterized by relatively small fire sizes will require finerresolution land cover data than we used, to reduce the influence of potential edge-effects on results and to enable exposure assessments over shorter (i.e., $\leq 100$ m) distance ranges.
Mixedwood, $K U$ Kazan Uplands, $U F$ Upper Foothills, $U B H$ Upper Boreal Highlands, $R M$ Rocky Mountain, $L F$ Lower Foothills, $C M$ Central Mixedwood, AP Athabasca Plain, DM Dry Mixedwood

Key assumptions

Our fuel-based exposure metric ignores information about topographic conditions, such as slope or aspect, which are known to influence fire behaviour. For a given fuel complex, slope can be expected to accelerate combustion and fire spread rates in comparison with flat terrain by enabling faster preheating of upslope fuels (van Wagtendonk 2006). Presence of complex topography in our study area was largely limited to the Rocky Mountain ecological unit, where the metric performed well. We suspect that slope and aspect have a minimal influence on the exposure metric due to the homogenized weather and fuel moisture conditions described above for large fires, such that locations exposed to hazardous fuel will burn, irrespective of the contribution of slope or other 
Table 3 Proportion of observed burned areas with hazard fuel exposure $\geq 80 \%$ and $\geq 60 \%$ compared with the corresponding proportion across the ecological unit as a whole (i.e., the null model) for two extents: (a) all burned areas; and (b) a random sample covering 0.005 of the burned area

\begin{tabular}{|c|c|c|c|c|c|c|c|c|}
\hline \multirow[t]{3}{*}{ Ecological unit } & \multicolumn{4}{|c|}{ (a) All burned areas } & \multicolumn{4}{|c|}{ (b) Sampled locations } \\
\hline & \multicolumn{2}{|c|}{ Exposure $\geq 80 \%$} & \multicolumn{2}{|c|}{ Exposure $\geq 60 \%$} & \multicolumn{2}{|c|}{ Exposure $\geq 80 \%$} & \multicolumn{2}{|c|}{ Exposure $\geq 60 \%$} \\
\hline & Expected & Observed & Expected & Observed & Expected & Observed & Expected & Observed \\
\hline BSA & 0.33 & 0.58 & 0.47 & 0.77 & 0.33 & $0.59^{\mathrm{a}}$ & 0.48 & $0.78^{\mathrm{a}}$ \\
\hline AP & 0.73 & 0.77 & 0.88 & 0.91 & 0.73 & $0.76^{\mathrm{a}}$ & 0.89 & $0.92^{\mathrm{a}}$ \\
\hline $\mathrm{KU}$ & 0.56 & 0.69 & 0.76 & 0.90 & 0.57 & $0.70^{\mathrm{a}}$ & 0.76 & $0.90^{\mathrm{a}}$ \\
\hline UF & 0.56 & 0.71 & 0.78 & 0.88 & 0.56 & $0.74^{\mathrm{b}}$ & 0.78 & $0.89^{\mathrm{c}}$ \\
\hline LF & 0.24 & 0.33 & 0.46 & 0.60 & 0.24 & $0.31^{\mathrm{c}}$ & 0.46 & $0.56^{\mathrm{b}}$ \\
\hline $\mathrm{UBH}$ & 0.52 & 0.70 & 0.73 & 0.88 & 0.52 & $0.70^{\mathrm{a}}$ & 0.72 & $0.88^{\mathrm{a}}$ \\
\hline $\mathrm{LBH}$ & 0.24 & 0.51 & 0.44 & 0.74 & 0.25 & $0.52^{\mathrm{a}}$ & 0.43 & $0.73^{\mathrm{a}}$ \\
\hline NM & 0.31 & 0.48 & 0.53 & 0.76 & 0.31 & $0.47^{\mathrm{a}}$ & 0.53 & $0.75^{\mathrm{a}}$ \\
\hline DM & 0.04 & 0.06 & 0.11 & 0.15 & 0.04 & $0.06^{\mathrm{a}}$ & 0.11 & $0.15^{\mathrm{a}}$ \\
\hline $\mathrm{CM}$ & 0.18 & 0.28 & 0.34 & 0.52 & 0.18 & $0.28^{\mathrm{a}}$ & 0.34 & $0.53^{\mathrm{a}}$ \\
\hline $\mathrm{RM}$ & 0.49 & 0.69 & 0.68 & 0.84 & 0.49 & $0.65^{\mathrm{b}}$ & 0.68 & $0.85^{\mathrm{b}}$ \\
\hline
\end{tabular}

Due to the presences of spatial autocorrelation in the data, tests for significant differences apply only to sampled locations

${ }^{a}$ Significantly greater than the null proportion (Chi-squared, $\mathrm{p}<0.001$ )

${ }^{\mathrm{b}}$ Significantly greater than the null proportion (Chi-squared, $\mathrm{p}<0.01$ )

${ }^{\mathrm{c}}$ Significantly greater than the null proportion (Chi-squared, $\mathrm{p}<0.05$ )

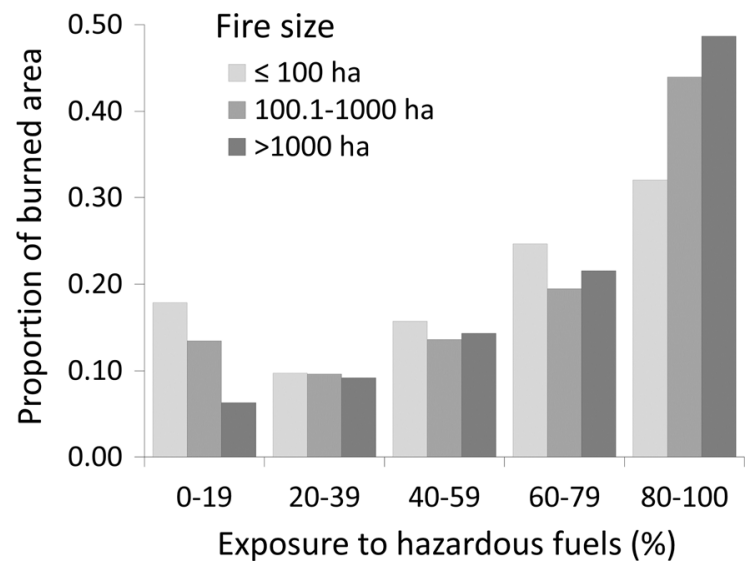

Fig. 4 Distribution of exposure values in subsequently burned areas, by fire size class for the study area, excepting the Dry Mixedwood ecological unit

topographic variables towards combustion rates. While it was not a factor in our study area, further research will be necessary to explore the influence of weather, topographic conditions and other fire controls on metric performance in other fire regime contexts and geographic locations.
We used a $500 \mathrm{~m}$ fuel neighbourhood following Beverly et al. (2010). In that study, a literature review and theoretical model (i.e., Albini's 1979) was used to define the distance range associated with ember transmission. Our results suggest the $500 \mathrm{~m}$ fuel neighbourhood was effective for assessing fire exposure within our study area. In other geographical areas, fire transmission may be driven by heat transfer mechanisms operating at different distance ranges, which could necessitate use of finer-resolution land cover data and may potentially explain the poor results in the Dry Mixedwood ecological unit.

Limitations of fuel data and fuel hazard classification

Exposure to hazardous fuels will reflect the resolution and accuracy of the land cover grid; and the subjective classification of these land cover types into a binary hazardous fuel grid. Fuel conditions in low exposure areas that burned provide some insight into the limitations of fuel data used in this study. For example, in the Central Mixedwood ecological unit, $65 \%$ of low 

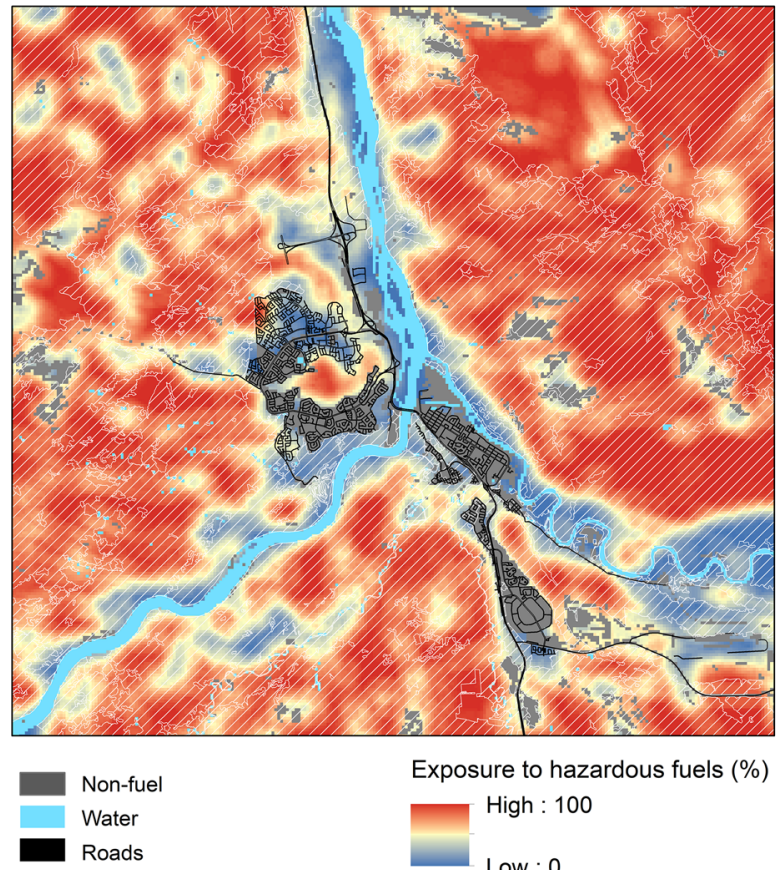

Exposure to hazardous fuels (\%)

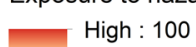

Low : 0

$\begin{array}{lll}0 & 2.5 \quad 5\end{array}$

Fig. 5 Exposure to hazardous fuels for the 2016 assessment year in the Fort McMurray area of Alberta (left panel). Burn probabilities simulated with the Burn-P3 model by Beverly and

exposure areas that burned were associated with aspen and grass fuels derived from inventory data $>15$ years old and roughly one third of the low exposure areas that burned coincided with open peatlands. Boreal peatlands are known to resist fire spread when wet and conduct fire spread when dry (Thompson et al. 2019), such that classification as a hazardous fuel is dependent on drought conditions. Three quarters of the low exposure areas that burned in the Lower Foothills ecological unit were associated with prior disturbances in the form of harvest cutblocks (56\%) and fires (19\%). Previously burned or harvested areas are often designated as a grass fuel type for a period of time, which we considered a non-hazard for longer-range ember transmission, but these areas may actually contain sufficient regeneration to constitute a hazardous fuel classification. Likewise, we designated aspen stands a non-hazardous fuel that does not contribute to longer-range ember transmission, but these stands can sometimes have a well-developed spruce understory that has been shown to contribute to

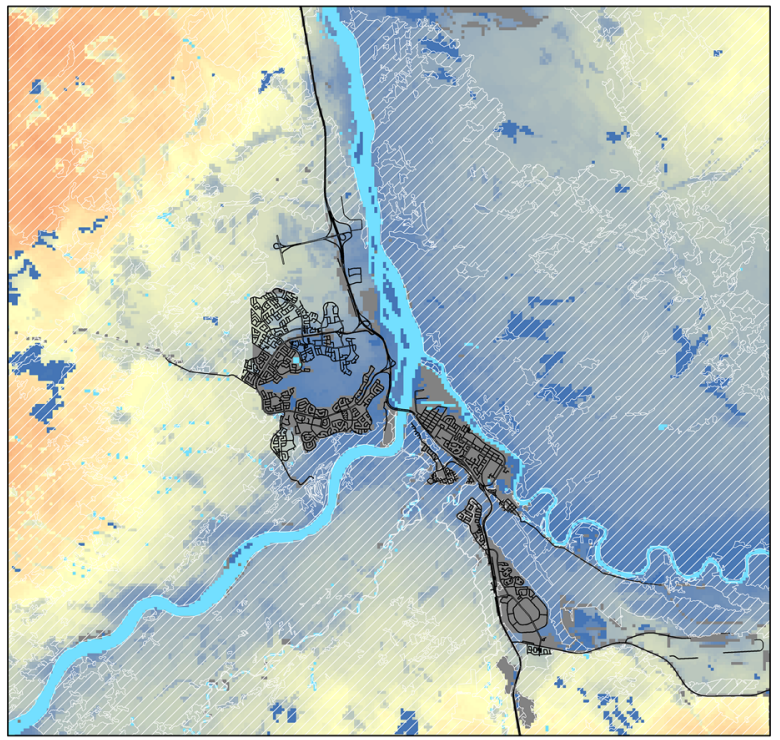

Simulated Burn Probability (Burn-P3)

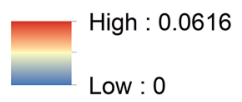

McLoughlin (2019) for the same location and year. White hatch lines denote areas burned by the 2016 Horse River Fire (right panel)

fire severity in Alberta (Greene et al. 2005), and would therefore constitute a hazardous fuel.

We expect enhanced land cover mapping would improve performance of the exposure metric as would use of underlying data sources to characterize hazardous fuels, such as the Alberta Vegetation Inventory and supplementary data sources in the form of wetland and ecosite mapping products. We opted to classify hazard fuels using FBP System fuel types following Beverly et al. (2010), primarily because these fuel types are well-known and understood by Canadian fire managers and researchers and are used in a wide range of fire research investigations and fire management tools. Fuel mapping capabilities are undergoing radical change due to new data collection methods including very high spatial resolution optical satellite data (e.g., Ahmed et al. 2018), airborne laser scanning (ALS) (e.g., Cameron 2020) and unmanned aerial vehicles (UAVs) combined with LiDAR (e.g., Shin et al. 2018; Fernandez-Alvarez et al. 2019) and computer image processing with machine learning (ML) methods (Guimarães et al. 2020). These new 
fuel data sources can be expected to generate more accurate hazardous fuel classifications in the future. Field visits to assess fuels in low-exposure areas that burned could potentially help to identify weaknesses and limitations in current fuel data and inform strategies for mapping hazardous fuels in the future.

Following Beverly et al. (2010), ignition exposure was assessed for combined spring and summer seasons. In that study, if a fuel type was considered a hazard in any season, it was classified as a hazardous fuel. Fuels such as grass and aspen are considered hazardous fuels during spring conditions, but only transmit fire over relatively short distances that were not represented by the coarse resolution of our land cover raster, and were therefore omitted. Assessments conducted at a finer spatial resolution could partition exposure by spring and summer, such that grass and aspen would be classified a hazardous fuel in spring but not summer.

Practical applications and relevance to fire risk assessment

Exposure to hazardous fuels can be assessed in minutes for large landscapes by one variable at virtually no marginal cost using rudimentary GIS techniques. Our landscape fire exposure metric is a numeric rating of the potential for fire transmission to a location given surrounding fuel composition and configuration, irrespective of weather or other fire controls. This simple, deterministic, univariate metric of fire exposure aligned well with real-world fires observed in our study area and represents a departure from computationally complex and data-intensive approaches for characterizing fire spread potential across landscapes.

Simple landscape fire metrics have received limited research attention, possibly due to a dominant fire risk modelling paradigm in which probabilistic assessments of fire likelihood are deemed compulsory. Thompson and Calkin (2011) define fire risk as a function of burn probability, conditional fire intensity, and fire effects. Similarly, recent reviews of wildfire risk assessment methods define fire risk as the combination of fire probability, fire behaviour and fire effects (Xi et al. 2019), or simply the product of fire probability and potential impact (Johnston et al. 2020). In landscapes where the likelihood of burning is low, such as the boreal forest, complex probabilistic modelling efforts may yield little insight into which locations can be expected to burn over the next or several years (Beverly and McLoughlin 2019). Flage et al. (2014) argue that probabilities are not well suited for characterizing the risk of rare events with potential catastrophic consequences and suggest alternatives such as possibilistic measures or qualitative methods in these cases.

The conceptual contribution of our exposure metric to landscape fire likelihood assessment is illustrated in Fig. 6. In probabilistic models of fire likelihood, the integrated expression of fire controls is studied through analysis of discrete fire events compiled from historical data or simulations. Landscape burn probabilities are estimated from computationally complex simulation models or predictive statistical models. Unfortunately, because burn probabilities are investigated through the narrow lens of discrete fire events, results are limited to conditions represented within the analysed set of fires and associated mix of static and dynamic fire controls, which may or may not represent possible or likely fire outcomes in the future. In contrast, decoupled metrics of fire controls are generated with direct measurement of the fire control itself in a deductive approach that facilitates broad generalization and ease of estimation across large areas. This approach is well established for mapping spatial variation in weather controls on fuel moisture and fire behaviour, which are estimated over a range of time scales (i.e., daily, annual, decadal), irrespective of fuel conditions.

Fire weather indices are calculated and mapped across entire countries solely from weather station measurements of temperature, relative humidity, wind speed and precipitation (i.e., Van Wagner 1987). These metrics omit fuel conditions but are wellestablished as significant predictors of wildfire activity and have made important contributions to the study of fire processes, such as facilitating temporal comparisons instrumental for detecting climate change impacts (e.g., Flannigan et al. 2005). Efforts to develop comparable fuel-based metrics may have been eclipsed by the availability of complex fire spread simulation models, which have the perceived advantage of accounting for spatial context in the assessment of fire-prone locations. Figure 6 illustrates the conceptual process of evaluating landscape fire exposure in relation to multiple independently derived metrics of fire controls, such as fire weather indices, 
(a) FIRE LIKELIHOOD - INTEGRATED FIRE CONTROLS

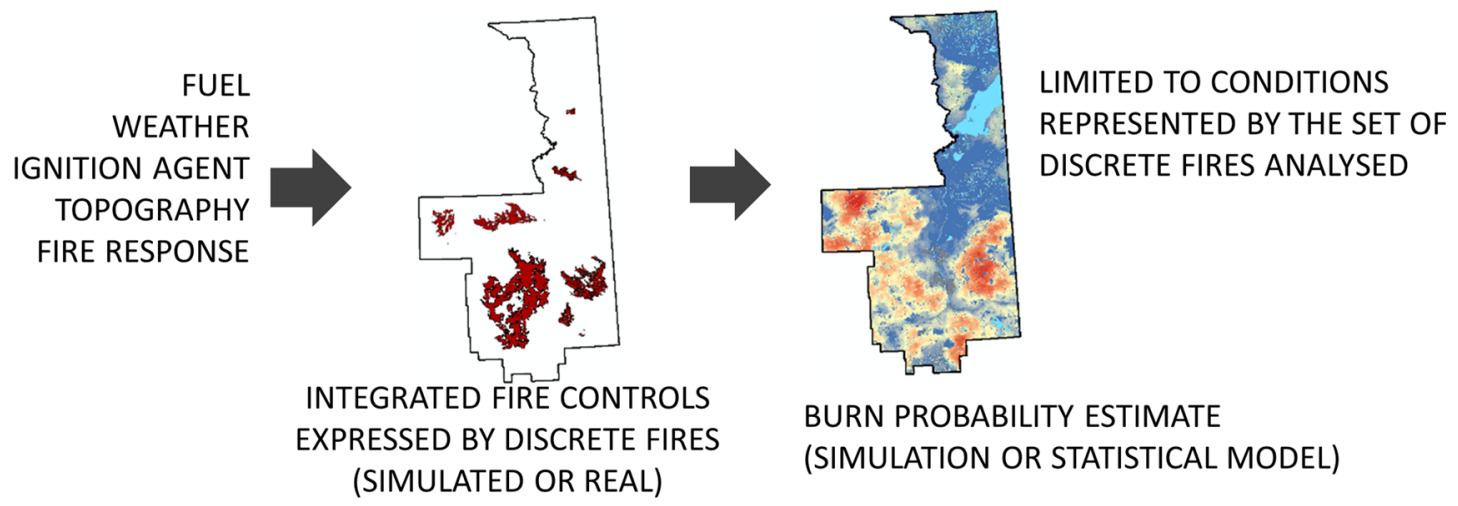

(b) FIRE LIKELIHOOD - DECOUPLED FIRE CONTROLS

ASSESS OTHER METRICS OF FIRE CONTROLS (IF RELEVANT)

FUEL

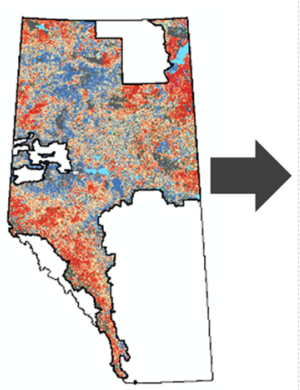

LANDSCAPE

FIRE EXPOSURE
WEATHER

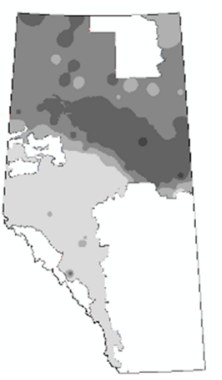

FIRE WEATHER

INDICES

\section{IGNITION AGENTS}

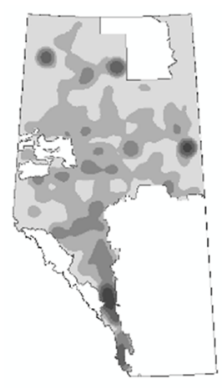

IGNITION

FREQUENCIES
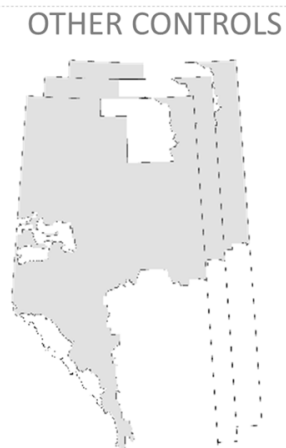

TOPOGRAP $\bar{P} \mathrm{HY}^{-1}$ FIRE RESPONSE...
OBSERVED FIRES

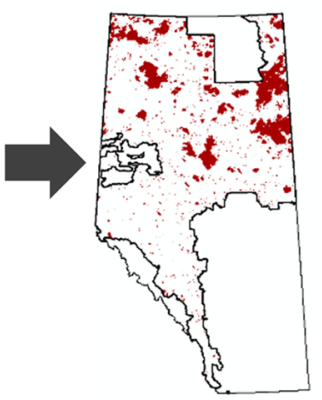

TEST ALIGNMENT
DAILY

ANNUAL
ANNUAL

DECADAL
DAILY

ANNUAL

DECADAL

\section{DAILY \\ ANNUAL \\ DECADAL}

Fig. 6 Conceptual contribution of the exposure metric to landscape fire risk modelling. a In probabilistic models of fire likelihood, the integrated expression of fire controls is studied through analysis of discrete fire events compiled from historical observations or simulations. Landscape burn probabilities are estimated from simulation or predictive statistical models and are limited to conditions represented by the set of analysed fire

ignition frequencies, topography or fire response. Our results suggest that exposure alone can also provide reliable insight about which landscape locations are most prone to burning, a finding consistent with prior studies (e.g., Krawchuk et al. 2006; Beverly 2017) that suggest vegetation feedbacks strongly regulate fire in our study area. events. b Decoupled metrics of fire controls can be used alone or in combination with other relevant fire controls to infer fire likelihood. These metrics are estimated from a deductive approach that facilitates broad generalization and ease of estimation across large areas. The approach is validated by testing for alignment with observed wildfires

Future research

In our study area, pre-existing, coarse-scale fuel type data were sufficient for accurately assessing spatial variation in fire exposure in ten of eleven ecological units examined, despite the many limitations of these fuel data. Our fire exposure metric also performed well 
despite ignoring most of the variables commonly used to assess potential fire behaviour and fire likelihood at the landscape scale, including topography, weather, wind speed and direction, season, and fire regime characteristics typically derived from historical data such as ignition agents, ignition patterns and fire frequency. Further research will be required to assess the individual contribution of exposure and other decoupled fire controls towards overall fire likelihood in an area, for example by using exposure as an input to probabilistic statistical models. Predictive models of fire occurrence could also be used to assess the influence of our exposure metric in relation to other landscape metrics (e.g., Vega-Garcia and Chuvieco 2006). Further study is also needed to explore practical applications of the exposure metric for documenting landscape change over time and for informing fire management decisions such as proactive vegetation management and evacuation planning. While the results of our study are promising, the exposure metric will require further evaluation for use in ecosystems that depart from the fire regime and fire environment characteristics of our study area.

Acknowledgements We thank D.L. Martell (University of Toronto), S.G. Cumming (Université Laval), M.E. Alexander (Canadian Forest Service, retired), the Coordinating Editor and two anonymous reviewers for providing helpful comments on an earlier version of the manuscript.

Author contributions JLB designed the study, conducted the analysis and drafted the manuscript. NM and EC prepared and documented data; and contributed to analysis, interpretation of results and associated data summaries. All authors read and approved the final manuscript.

\section{Compliance with ethical standards}

Conflict of interest The authors declare that they have no conflict of interest.

Open Access This article is licensed under a Creative Commons Attribution 4.0 International License, which permits use, sharing, adaptation, distribution and reproduction in any medium or format, as long as you give appropriate credit to the original author(s) and the source, provide a link to the Creative Commons licence, and indicate if changes were made. The images or other third party material in this article are included in the article's Creative Commons licence, unless indicated otherwise in a credit line to the material. If material is not included in the article's Creative Commons licence and your intended use is not permitted by statutory regulation or exceeds the permitted use, you will need to obtain permission directly from the copyright holder. To view a copy of this licence, visit http://creativecommons.org/licenses/by/4.0/.

\section{References}

Ager AA, Vaillant NM, Finney MA, Preisler HK (2012) Analyzing wildfire exposure and source-sink relationships on a fire prone forest landscape. For Ecol Manag 267:271-283

Ahmed MR, Rahaman KR, Hassan QK (2018) Remote sensing of wildland fire-induced risk assessment at the community level. Sensors 18:1570

Albini FA (1979) Spot fire distance from burning trees-a predictive model. USDA For. Serv. Gen. Tech. Rep. INT56. https://www.frames.gov/documents/behaveplus/ publications/Albini_1979_INT-GTR-056_ocr.pdf. Accessed 22 Feb 2020

Amiro BD, Logan KA, Wotton BM, Flannigan MD, Todd JB, Stocks BJ, Martell DL (2004) Fire weather index system components for large fires in the Canadian boreal forest. Int J Wildland Fire 13:391-400

Baartman JEM, Melsen LA, Moore D, van der Ploeg MJ (2020) On the complexity of model complexity: viewpoints across the geosciences. CATENA 186:104261

Beverly JL (2017) Time since prior wildfire affects subsequent fire containment in black spruce. Int $\mathbf{J}$ Wildland Fire 26:919-929

Beverly JL, McLoughlin N (2019) Burn probability simulation and subsequent wildland fire activity in Alberta, Canadaimplications for risk assessment and strategic planning. For Ecol Manag 451:117490

Beverly JL, Herd EPK, Conner JCR (2009) Modeling fire susceptibility in west central Alberta, Canada. For Ecol Manag 258:1465-1478

Beverly JL, Bothwell P, Conner JCR, Herd EPK (2010) Assessing the exposure of the built environment to potential ignition sources generated from vegetative fuel. Int J Wildland Fire 19:299-313

Cameron H (2020) Predicting fuel characteristics of black spruce stands using airborne laser scanning (ALS) in the province of Alberta, Canada. MSc Thesis, University of Alberta, 2020, p 122

Collie JS, Botsford LW, Hastings A, Kaplan I, Largier J, Livingston PA, Plaganyi E, Rose KA, Wells BK, Werner FE (2016) Ecosystem models for fisheries management: finding the sweet spot. Fish Fish 17(1):101-125

Conver JL, Falk DA, Yool SR, Parmenter RR (2018) Modeling fire pathways in montane grassland-forest ecotones. Fire Ecol 14:17-31

Countryman CM (1977) Heat and wildland fire, part 3: heat conduction and wildland fire. USDA Forest Service, Pacific Southwest Forest and Range Experiment Station, Berkeley, p 17

Cunningham AA, Martell DL (1973) A stochastic model for the occurrence of man-caused forest fires. Can J For Res 3:282-287

Falk DA, Miller C, McKenzie D, Black AE (2007) Cross-scale analysis of fire regimes. Ecosystems 10:809-823 
Fernandez-Alvarez M, Armesto J, Picos J (2019) LiDAR-based wildfire prevention in WUI: the automatic detection, measurement and evaluation of forest fuels. Forests 10(2): 148

Finney MA (2002) Fire growth using minimum travel time methods. Can J For Res 32:1420-1424

Finney MA (2004) FARSITE: fire area simulator-model development and evaluation. USDA Forest Service RMRS-RP-4 Revised, Rocky Mountain Research Station, Ogden

Finney MA (2006) An overview of FlamMap fire modeling capabilities. In: Andrews PL, Butler BW (eds) Fuels management-how to measure success: conference proceedings. USDA Forest Service RMRS-P-41, Rocky Mountain Research Station, Fort Collins, p 41

Finney MA (2007) A computational method for optimising fuel treatment locations. Int J Wildland Fire 16:702-711

Finney MA, McHugh CW, Grenfell IC, Riley KL, Short KC (2011) A simulation of probabilistic wildfire risk components for the continental United States. Stoch Environ Res Risk Assess 25:73-1000

Flage R, Aven T, Zio E, Baraldi P (2014) Concerns, challenges, and directions of development for the issue of representing uncertainty in risk assessment. Risk Anal 34:1196-1207

Flannigan MD, Harrington JB (1988) A study of the relation of meteorological variables to monthly provincial area burned by wildfire in Canada 1953-80. J Appl Meteorol 27:441-452

Flannigan MD, Logan K, Amiro B, Skinner W, Stocks B (2005) Future area burned in Canada. Clim Change 72:1-16

Forestry Canada Fire Danger Group (1992) Development and structure of the Canadian forest fire behavior prediction system. Forestry Canada, Ottawa, ON. Information report ST-X-3, p 63

Getz WM, Marshall CR, Carlson CJ, Giuggioli L, Ryan SJ, Romañach SS, Boettiger C, Chamberlain SD, Larsen L, D’Odorico P, Sullivan D (2018) Making ecological models adequate. Ecol Lett 21:153-166

Gray M, Dickson BG (2015) A new model of landscape-scale fire connectivity applied to resource and fire management in the Sonoran Desert, USA. Ecol Appl 25(4):1099-1113

Greene DF, Macdonald SE, Cumming S, Swift L (2005) Seedbed variation from the interior through the edge of a large wildfire in Alberta. Can J For Res 35:1640-1647

Guimarães N, Pádua L, Marques P, Silva N, Peres E, Sousa JJ (2020) Forestry remote sensing from unmanned aerial vehicles: a review focusing on the data, processing and potentialities. Remote Sens 12:1046

Gustafson EJ (2013) When relationships estimated in the past cannot be used to predict the future: using mechanistic models to predict landscape ecological dynamics in a changing world. Landsc Ecol 28:1429-1437

Gustafson EJ (2019) How has the state-of-the-art for quantification of landscape pattern advanced in the twenty-first century? Landsc Ecol 34:2065-2072

Haas JR, Calkin DE, Thompson MP (2013) A national approach for integrating wildfire simulation modeling into Wildland Urban Interface risk assessments within the United States. Landsc Urban Plan 119:44-53

Hardy CC (2005) Wildland fire hazard and risk: problems, definitions, and context. For Ecol Manag 211(1-2):73-82
Holsinger L, Parks SA, Miller C (2016) Weather, fuels, and topography impede wildland fire spread in western US landscapes. For Ecol Manag 380(15):59-69

ISO (2009) ISO Guide 73. Risk management-vocabulary. International Organization for Standardization, Geneva, p 15

Johnston LM, Wang X, Erni S, Taylor SW, McFayden C, Oliver JA, Stockdale C, Christianson A, Boulanger Y, Gauthier S, Arseneault D, Wotton BM, Parisien M-A, Flannigan MD (2020) Wildland fire risk research in Canada. Environ Rev 28(2):164-186

Krawchuk MA, Cumming SG, Flannigan MD, Wein RW (2006) Biotic and abiotic regulation of lightning fire initiation in the mixedwood boreal forest. Ecology 87:458-468

Larsen LG, Eppinga MB, Passalacqua P, Getz WM, Rose KA, Liang M (2016) Appropriate complexity landscape modeling. Earth-Sci Rev 160:111-130

Li HB, Reynolds JF (1993) A new contagion index to quantify spatial patterns of landscapes. Landsc Ecol 8(3):155-162

Macauley KA (2020) Modelling fire cessation in the Canadian Rocky Mountains. MSc Thesis, University of Alberta, p 80

Martell DL, Otukol S, Stocks BJ (1987) A logistic model for predicting daily people-caused forest fire occurrence in Ontario. Can J For Res 17:394-401

McGarigal K, Marks BJ (1995) Fragstats: spatial pattern analysis program for quantifying landscape structure, general technical report PNW-GTR-351. US Forest Service Pacific Northwest Research Station, Portland

McKenzie D, Miller C, Falk DA (2011) The landscape ecology of fire. Ecological studies series, vol 213. Springer Publishing Services, London

MNP (2017) A review of the 2016 Horse River Wildfire: Alberta agriculture and forestry preparedness and response. MNP: Edmonton, AB, Canada

Murray AB (2003) Contrasting the goals, strategies, and predictions associated with simplified numerical models and detailed simulations. In: Iverson RM, Wilcock PR (eds) Prediction in Geomorphology, Geophysical Monograph Series 135. American Geophysical Union, Washington, DC, pp 151-165

Murray AB (2007) Reducing model complexity for explanation and prediction. Geomorphology 90:178-191

Narayanaraj G, Wimberly MC (2011) Influences of forest roads on the spatial pattern of wildfire boundaries. Int J Wildland Fire 20(6):792-803

Natural Regions Committee (2006) Natural regions and subregions of Alberta. Publication T/852. Compiled by: Downing DJ, Pettapiece WW (eds) Government of Alberta, Edmonton. https://albertaparks.ca/media/ 2942026/nrsrcomplete_may_06.pdf

Newman EA, Kennedy MC, Falk DA, McKenzie D (2019) Scaling and complexity in landscape ecology. Front Ecol Evol 7:293

O'Connor CD, Calkin DE, Thompson MP (2017) An empirical machine learning method for predicting potential fire control locations for pre-fire planning and operational fire management. Int J Wildland Fire 26(7):587-597

O’Neill RV, Krummel JR, Gardner RH, Sugihara G, Jackson B, DeAngelis DL, Milne BT, Turner MG, Zygmunt B, Christensen SW, Dale VH, Graham RL (1988) Indices of landscape pattern. Landsc Ecol 1(3):153-162 
Page WG, Wagenbrenner NS, Butler BW, Blunck DL (2019) An analysis of spotting distances during the 2017 fire season in the Northern Rockies, USA. Can J For Res 49:317-325

Papadopoulos GD, Pavlidou F-N (2011) A comparative review on wildfire simulators. IEEE Syst J 5:233-243

Parisien MA, Kafka VG, Hirsch KG, Todd JB, Lavoie SG, Maczek PD (2005) Mapping wildfire susceptibility with the Burn-P3 simulation model. Canadian Forest Service. Northern Forestry Centre, Edmonton, AB. Information Report NOR-X-405

Parisien M-A, Miller C, Ager AA, Finney MA (2010) Use of artificial landscapes to isolate controls on burn probability. Landsc Ecol 25(1):79-93

Perera AH, Sturtevant BR, Buse L (2015) Simulation modeling of forest landscape disturbances: an overview. In: Perera AH, Sturtevant BR, Buse LJ (eds) Simulation modeling of forest landscape disturbances. Springer, Geneva, pp 1-15

Perry GLW (1998) Current approaches to modelling the spread of wildland fire: a review. Prog Phys Geogr 22(2):222-245

Peterson D (2002) Contagious disturbance, ecological memory, and the emergence of landscape pattern. Ecosystems $5: 329-338$

Pickett ST, Cadenasso ML (1995) Landscape ecology: spatial heterogeneity in ecological systems. Science 269(5222):331-334

Podur JJ, Wotton BM (2011) Defining fire spread event days for fire-growth modelling. Int J Wildland Fire 20:497-507

Resource Information Management Branch (2005) Vegetation inventory standards and data model documents. Version 2.1.1. Alberta Sustainable Resource Development, Resource Information Management Branch, Edmonton, Alberta. https://www.alberta.ca/vegetation-inventorystandards.aspx

Riitters KH, O’Neill RV, Wickham JD, Jones KB (1996) A note on contagion indices for landscape analysis. Landsc Ecol 11:197-202

Rodrigues M, Alcasena F, Gelabert P, Vega-García C (2020) Geospatial modeling of containment probability for escaped wildfires in a Mediterranean region. Risk Anal 40(9):1762-1779

Rothermel RC (1972) A mathematical model for predicting fire spread in wildland fuels. USDA Forest Service, Ogden

Sánchez-Azofeifa GA, Chong M, Sinkwich J, Mamet S (2004) Alberta Ground Cover Classification (AGCC) training and procedures manual. Earth Observations Systems Laboratory. Department of Earth and Atmospheric Sciences. University of Alberta. Edmonton, AB

Shin P, Sankey T, Moore MM, Thode AE (2018) Evaluating unmanned aerial vehicle images for estimating forest canopy fuels in a ponderosa pine stand. Remote Sens 10:1266

Simard AJ (1991) Fire severity, changing scales, and how things hang together. Int J Wildland Fire 1:23-34

Srock A, Charney J, Potter B, Goodrick S (2018) The Hot-DryWindy Index: a new fire weather index. Atmosphere 9(7):279

Stockdale C, Barber Q, Saxena A, Parisien MA (2019) Examining management scenarios to mitigate wildfire hazard to caribou conservation projects using burn probability modeling. J Environ Manag 233:238-248
Stocks BJ, Mason JA, Todd JB, Bosch EM, Wotton BM, Amiro BD, Flannigan MD, Hirsch KG, Logan KA, Martell DL, Skinner WR (2002) Large forest fires in Canada, 1959-1997. J Geophys Res 108(D1):8149

Sullivan AL (2017) Inside the inferno: fundamental processes of wildland fire behaviour. Part 1: Combustion chemistry and heat release. Curr For Rep 3:132-149

Thompson MP, Calkin DE (2011) Uncertainty and risk in wildland fire management: a review. J Environ Manag 92:1895-1909

Thompson MP, Zimmerman T, Mindar D, Taber M (2016) Risk terminology primer: basic principles and a glossary for the wildland fire management community. Gen. Tech. Rep. RMRS-GTR-349. Fort Collins, CO: USDA Forest Service, Rocky Mountain Research Station, p 13

Thompson DK, Simpson BN, Whitman E, Barber QE, Parisien MA (2019) Peatland hydrological dynamics as a driver of landscape connectivity and fire activity in the Boreal Plain of Canada. Forests 10(7):1-21

Turner MG (1989) Landscape ecology: the effect of pattern on process. Annu Rev Ecol Syst 20:171-197

Turner MG, Romme WH (1994) Landscape dynamics in crown fire ecosystems. Landsc Ecol 9:59-77

Tymstra C, Bryce RW, Wotton BM, Taylor SW, Armitage OB (2010) Development and structure of Prometheus: the Canadian Wildland fire growth simulation model. Natural Resources Canada, Canadian Forest Service, Northern Forestry Centre, Edmonton, AB. Inf. Rep. 88 NOR-X-417

Van Wagner CE (1983) Fire behavior in northern conifer forests and shrublands. In: Wein RW, MacLean DA (eds) The role of fire in northern circumpolar ecosystems. Wiley, Chichester, pp 65-80

Van Wagner CE (1987) Development and structure of the Canadian Forest Fire Weather Index System. Canadian Forestry Service, Ottawa, ON. Forestry Technical Report 35

van Wagtendonk JW (2006) Fire as a physical process, pp 38-57. In: Sugihara NG, van Wagtendonk JW, Fites-Kaufman J, Shaffer KE, Thode AE (eds) Fire in California's ecosystems. University of California Press, Berkeley, p 578

Vega-Garcia C, Chuvieco E (2006) Applying local measures of spatial heterogeneity to Landsat-TM images for predicting wildfire occurrence in Mediterranean landscapes. Landsc Ecol 21:595-605

Walz U (2011) Landscape structure. Landscape metrics and biodiversity. Living Rev Landsc Res 5(3):1-35

White PS (1987) Natural disturbance, patch dynamics, and landscape pattern in natural areas. Nat Areas J 7:14-22

Whitman E, Rapaport E, Sherren K (2013) Modeling fire susceptibility to delineate wildland-urban interface for municipal-scale fire risk management. Environ Manag 52(6):1427-1439

Wotton BM, Martell DL (2005) A lightning fire occurrence model for Ontario. Can J For Res 35:1389-1401

Xi DDZ, Taylor SW, Woolford DG, Dean CB (2019) Statistical models of key components of wildfire risk. Annu Rev Stat Appl 6:197-222

Publisher's Note Springer Nature remains neutral with regard to jurisdictional claims in published maps and institutional affiliations. 